\title{
The primary health care environment and the impact on motivation and stress in
}

\section{nurses}

O ambiente da atenção primária e o impacto sobre a motivação e o estresse em enfermeiras

El ambiente de la atención primaria de salud y el impacto en la motivación y el estrés en enfermeras

\begin{abstract}
Objective: The focus of this study was to investigate the possible occupational stress the nurses perceived that in Basic Health Units (BHUs) and assess the major factors that motivate these employees' inside these primary healthcare centers. Methodology: Data was collected from 70 nurses working in 61 BHUs distributed in the South of Brazil. The stress was measured with the Nurses' Stress Inventory (NSI), and the determination of motivation was performed using Maslow's Hierarchy of Needs. The research has been taken up with special reference to administrative/assistance nurses. Results: The investigation showed that nurses are predominantly female (89.5\%) and $80.0 \%$ work equally in assistant care and administrative functions. Moreover, the data showed that $89.4 \%$ of nurses present moderate to higher stress scores as a consequence of the intrinsic work factors. Investigating the motivation, the higher level in the Maslow hierarchy was belonging, this could be related to the fact BHUs are inserted in communities with strong social connections and relationships with the population. Conclusion: Knowing the main factors responsible for stress in nurses at the BHUs are essential for future strategies to improve working conditions.
\end{abstract}

Keywords: Occupational health; Stress; Motivation; Basic health units.

\section{Resumo}

Objetivo: O foco deste estudo foi investigar o possível estresse ocupacional percebido pelos enfermeiros nas Unidades Básicas de Saúde (UBS) e avaliar os principais fatores que motivam esses funcionários na Atenção Primária em Saúde. Metodologia: Os dados foram coletados junto a 70 enfermeiras que atuam em 61 UBS distribuídas na região Sul do Brasil. O estresse foi avaliado através do com o Inventário de Estresse em Enfermeiro e a determinação da motivação mensurada utilizando o Motivograma desenvolvido por Maslow. A pesquisa foi realizada com referência especial aos enfermeiros administrativos/assistenciais. Resultados: A investigação revelou que os enfermeiros são predominantemente do sexo feminino $(89,5 \%)$ e $80,0 \%$ atuam igualmente nas funções assistenciais e administrativas. Além disso, os dados evidenciaram que $89,4 \%$ dos enfermeiros apresentam escores de estresse de moderado a alto, principalmente em decorrência dos fatores intrínsecos ao trabalho. Investigando-se a motivação, constatou-se que o nível superior da hierarquia de Maslow era o pertencimento, o que pode estar relacionado ao fato das UBS estarem inseridas em comunidades com forte vínculo social e relacionamento com a população. Conclusão: Conhecer os fatores causadores de estresse de enfermeiros na UBS são essenciais para que estratégias futuras de melhoria das condições de trabalho sejam realizadas.

Palavras-chave: Saúde ocupacional; Estresse; Motivação; Unidade básica de saúde. 


\begin{abstract}
Resumen
Objetivo: El enfoque de este estudio fue investigar el posible estrés laboral percibido por enfermeros en Unidades Básicas de Salud (UBS) y evaluar los principales factores que motivan a estos empleados en Atención Primaria de Salud. Metodología: Se recolectaron datos de 70 enfermeras que laboran en 61 UBS distribuidas en el sur de Brasil. El estrés se evaluó mediante el Nurse Stress Inventory y la determinación de la motivación se midió mediante el Motivogram desarrollado por Maslow. La investigación se llevó a cabo con especial referencia a las enfermeras administrativas/asistenciales. Resultados: La investigación reveló que las enfermeras son predominantemente mujeres $(89,5 \%)$ y el $80,0 \%$ trabaja por igual en funciones asistenciales y administrativas. Además, los datos mostraron que el $89,4 \%$ de los enfermeros tenían puntuaciones de estrés que oscilaban entre moderado y alto, principalmente debido a factores intrínsecos a su trabajo. Investigando la motivación, se encontró que el nivel más alto de la jerarquía de Maslow era la pertenencia, lo que puede estar relacionado con el hecho de que las UBS están insertadas en comunidades con fuertes vínculos sociales y relación con la población. Conclusión: Conocer los factores estresantes de los enfermeros de la UBS es fundamental para desarrollar estrategias futuras de mejora de las condiciones laborales.
\end{abstract}

Palabras clave: Salud ocupacional; Estrés; Motivación; Unidades básicas de salud.

\title{
1. Introduction
}

Brazil was one of first Latin America's countries to provide universal health coverage for the population, as a fundamental right of the State (Gragnolati et al., 2013). The constitutional reform of the 80s created the Unified Health System (Sistema Único de Saúde - SUS) (Viana \& Machado, 2008). But as a continental country, with over 200 million people distributed in the five different geographic regions, decentralization strategies were necessary to improve the efficacy of health services. The solution came with the creation of small and structured organizations inside the communities, the Basic Health Units (BHUs), to improve the implementation of healthcare based on needs, enhancing equities (Gragnolati et al., 2013).

In the last two decades, the number of BHUs has grown, improving access to public health services, collaborating to the reduction of social inequities (Carvalho et al., 2014). But with decentralization, problems emerged, such as limited resources, bureaucracy barriers, insufficient and unqualified personnel (Oliveira et al., 2017).

Nurses are one of the most important, if not the most important human resource in BHUs, performing administrative and assistant roles. But work conditions, team management, and patient's care are sources of occupational stress (Carvalho et al., 2014).

Occupational stress is considered a healthcare worker's problem (Sarafis et al., 2016). The National Institute for Occupational Safety and Health (NIOSH) described it as "the harmful physical and emotional responses that occur when the requirements of the job do not match the capabilities, resources, or needs of the worker" (Sauter et al., 1999). Moreover, when workers perceive the job environment as threatening, with excessive demands and inadequate resources, the stress could emerge in employees and being exposed to stressful situations, could interfere in employee efficiency with negative consequences in health (Jennings, 2008). The BHUs environment could contain some factors that negatively reverberate in health professionals such as lack of material and equipment, unprepared human resource, and the contact with poor communities, since most of the population that seek BHUs belongs to classes C, D, and E, (Leonelli et al., 2017) Brazilians from better economic classes prefer the private health insurance.

Certain occupations are believed to be more stressful than others, but Nursing has been classified worldwide, as a highly stressful profession, exposed to demands and pressures with strong consequences on employee motivation, quality of life, and care (Braithwaite, 2008). It is important to clarify that when the conditions that create stress are relieved, the underlying model of nursing work may prevail (McKnight et al., 2020). Work motivation is a major determinant of nurses' behavior and performance, influenced by social, economic and professional factors. Career development and adequate working conditions contribute to motivation in nursing practice (Kahiga, 2017). A research conducted by the World Health Organization (WHO) showed that human resources are the most valuable element in healthcare services (WHO, 2010), and nurse' motivation has a significant effect on the success of the BHUs, but the lack of job motivation in nurses has a powerful 
effect on the health client, showing that patient care outcomes are extremely influenced by nurses' motivational conduct (Cumber \& Elive, 2016).

Due to the importance that stress and motivated behavior has on performance at work and in people's lives, understanding the sources of stress, and what stimulates or frustrates nurses is a fundamental knowledge to attempt a better healthcare service. The purpose of the study was to identify the effects of the nurses' work environment of BHUs on occupational stress and job motivation.

\section{Methodology}

This research was performed as an observational cross-sectional study. This type of investigation is commonly used in Medical Science to examine the presence or absence of an outcome during a specific period of time (Wang \& Cheng, 2020).

\section{Study sample}

The target population was nurses who met the following inclusion criteria: Being employed by the BHUs and perform assistant and administrative activities at the institution for at least six months, eight hours a day for five days/week. The composition of the sample reflects the reality in BHUs, where nurses are responsible for the main functions after decentralization doing more than 150 home visits and 170 appointments within the BHU per month, plus the bureaucratic functions. Questionnaires were applied in 61 BHUs in different cities at the South of Brazil. The questionnaires were anonymous and self-administered.

\section{Socio-demographics}

The first part of the questionnaire contained questions about socio-demographic and work-related characteristics of the nurses.

\section{Occupational Stress}

This investigation adopted the Nurses' Stress Inventory (NSI), a classic stress assessment instrument developed in 2000 by Stacciarini and Tróccoli (2000). The NSI is a self-applicable questionnaire, composed of 44 items, and divided into three first-order scales (Interpersonal relationships, Role-related stressors, Intrinsic work factors), and a second subscale included for internal consistency. The interpersonal analysis with 17 questions, intrinsic work factors with 11 questions and finally, role-related stress with ten questions. Each item requires respondent ranges from 1 to 5 (" 1 never stressful" to "5 extremely stressful"). The higher the score, the more stressful the situation. Total and subscale scores can be derived from the instrument. Values of NSI between 44-97 are considered low stress, between 98-135, moderate stress and high levels of stress $\geq 136$.

\section{Maslow's Hierarchy of Needs}

Maslow's theory categorizes human needs into five broad groups: Physiological needs, Safety needs, Belongingness and love needs, Esteem needs, Self-actualization needs, in a growing an order of complexity. Nursing continues to be a leading field that has adopted Maslow's ideas to identify motivation in nurses. To measure motivation, a self-reported instrument based on the Maslow hierarchy that included 30 items divided, was applied (Maslow, 1943; Regis \& Porto, 2011). 


\section{Ethics}

The voluntary nature of participation was emphasized and the informed written consent was obtained from all participants with the assured of anonymity and confidentiality. Approval for the research was obtained from the BHUs principal manager and by the Ethical Review at Universidade do Planalto Catarinense, Brazil (Plataforma Brasil).

\section{Data analysis}

The internal consistency was estimated by Cronbach's alpha, the comparison between the subscales of stress was performed by the Kruskal-Wallis test, which is indicated for comparisons between three or more groups followed by Dunn's Multiple Comparison Test. Spearman rank correlation was performed to measure the relationship between two or more variables. Statistical significance was set at a $\mathrm{p}<0.05$. The data was analyzed by the program Statistica ${ }^{\circledR}$ software package (Stat Soft Inc., Tulsa, OK, USA).

\section{Results}

The first aspect evaluated was the correct completion of questionnaires, and the adherence to the requirements among the inclusion criteria. Thus, of the 70 nurses who would initially participate in this research, 60 correctly filled in the questionnaire.

The investigation focused on nurses who performed both assistant and management work showed that $80 \%$ performed both tasks equally ( $\mathrm{n}=48$ nurses). The results also revealed that respondents were predominantly female $(n=43,89.58 \%)$, with age varying between 26 to 45 years old, with an average of 31 years old (43.28\%), the median time since graduation was seven years $(55.55 \%)$, and the average time working at the BHUs was three years and five months $(37.5 \%)$.

To assess the internal consistency, the Cronbach's alpha coefficient was analyzed. The values attested a good internal consistency with results above 0.70 for both NSI and Mashow's Hierarchy of Needs.

Investigating the possible occupational stress using NSI, the group displayed a stress score of 130 (Table 1) that corresponds to a moderate level of stress.

Table 1. Sum score and mean stress score. Mean values, standard deviations (SD), and alpha reliability coefficients (A) for occupational stress.

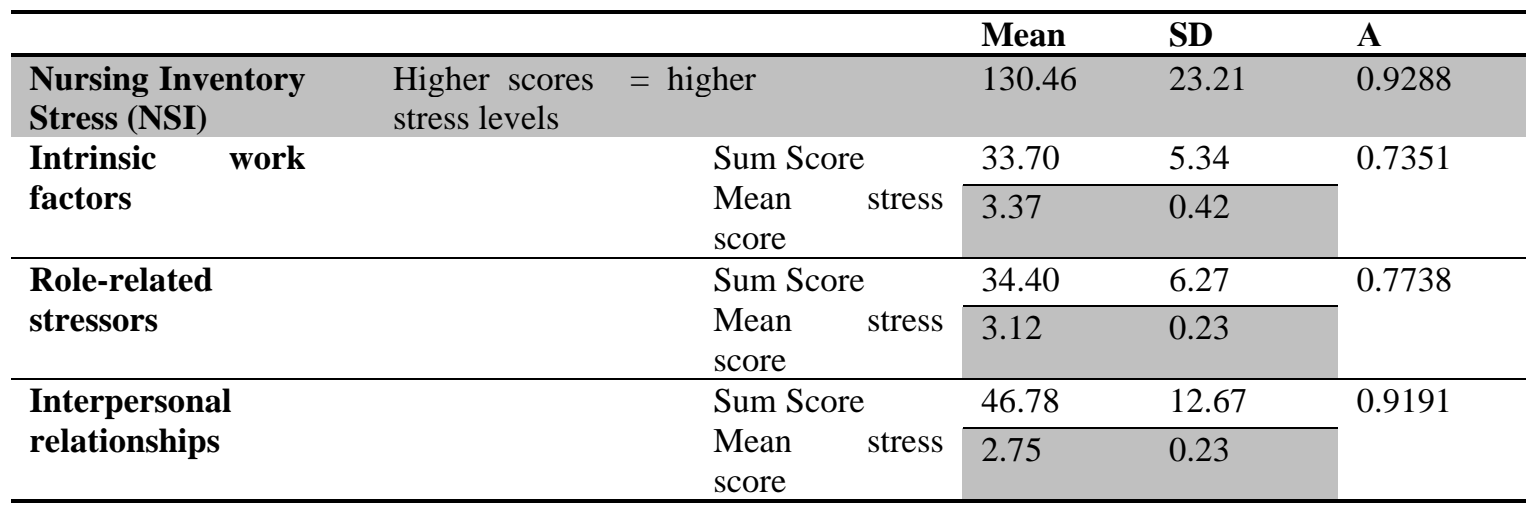

Source: The authors, (2021).

The Table 1 showed that nurses are more stressed about the Intrinsic work factors with a mean of 3.37 on a five-point scale. The table also reveals the mean score of stressors in the workplace. 
But, $44.7 \%$ of the population presents a score above 136, considered an indicator of strong stress in the profession, and only $10.6 \%$ present low stress score. Figure 1 illustrates the distribution of stress score between the nurses. Descriptive analysis showed a range of values between 81 and 171 (M: 130.46, SD: 23.21).

Figure 1: Distribution of the Stress Score in Nurses.

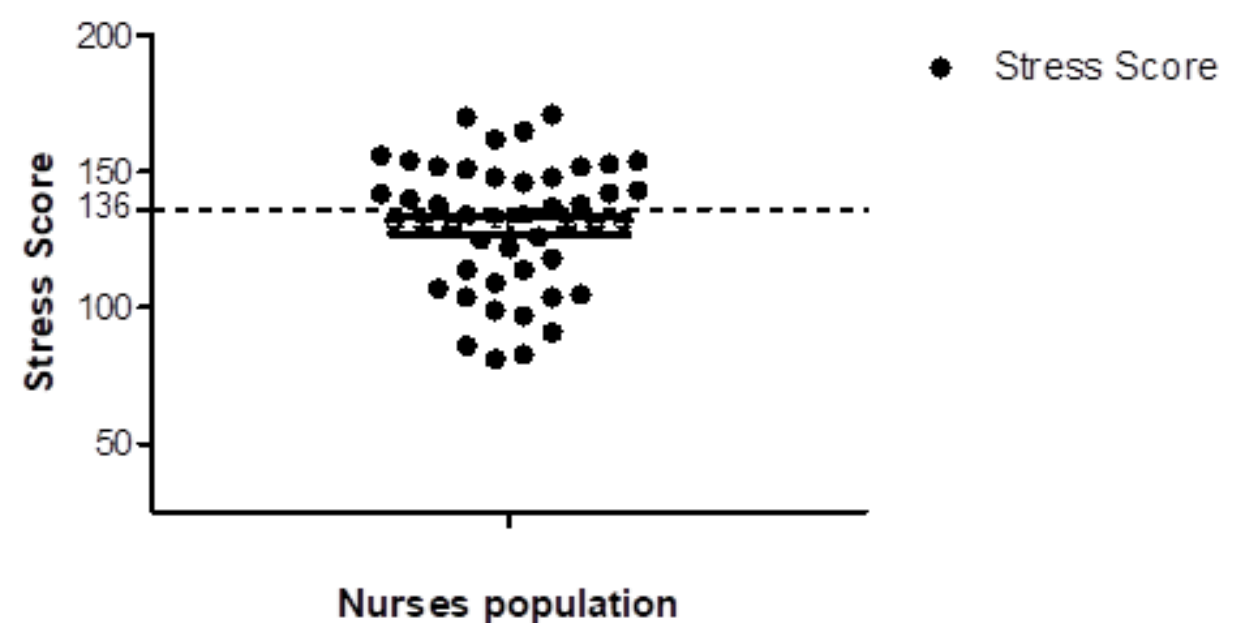

Source: The authors, (2021).

The Figure 1 reveals the main population in this study with moderate and higher levels of stress.

The analysis of the NSI subclasses showed the main complaint of possible causes of stress between nurses is the Intrinsic work factors (M: 3.37, SD: 0.42). This category had extremely significant values $(\mathrm{P}<0.001)$ when compared with Interpersonal Relations (M: 2.75, SD: 0.40). No statistical difference was shown between Intrinsic work factors and Rolerelated stressors (M: 3.12, SD: 0.23) (Figure 2).

Figure 2: The NSI first order scale.

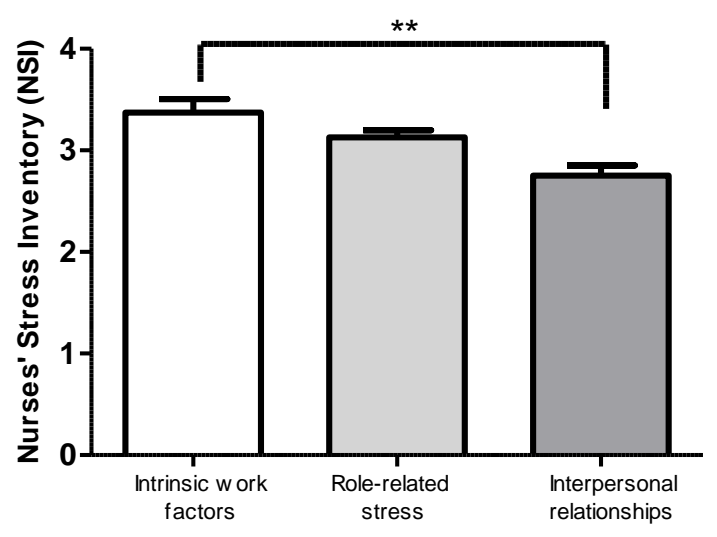

Source: The authors, (2021).

The Figure 2 showed the impact of intrinsic work factors upon nurses. The investigation of stress score in each category was performed. Statistical analysis was conducted by the Kruskal-Wallis test followed by Dunn's multiple comparison tests. $* *$ P-value $<0.001$. 
Exploring the instrument questions, "the absence of human resources", an intrinsic work factor subclass, was classified as stressful for the majority of nurses (M: 3.76, SD: 0.78). The question role-related stressor "Feeling impotent facing the tasks to perform" had the higher scores in subclass (M: 3.38, SD: 0.9), and the question "be responsible for the quality of service offered by the BHUs" received the higher score at the interpersonal relationships (M: 3.46, SD: 1.1). It is necessary to emphasize that values below 3 are classified as not stressful and above 3 as stressful.

The motivation score by Maslow Hierarchy of Needs was showed in Figure 3. The results are expressed by the median (M) and standard deviation (SD) (Physiological: M: 2.75, SD 0.54; Safety: M 2.84, SD 0.54; Belonging: M: 4.42, SD 0.64; Esteem: M 1.57, SD 0.41; Self-actualization: M: 3.40, SD: 0.58).

Figure 3: The motivation was investigated using the Maslow Hierarchy of Needs Score.

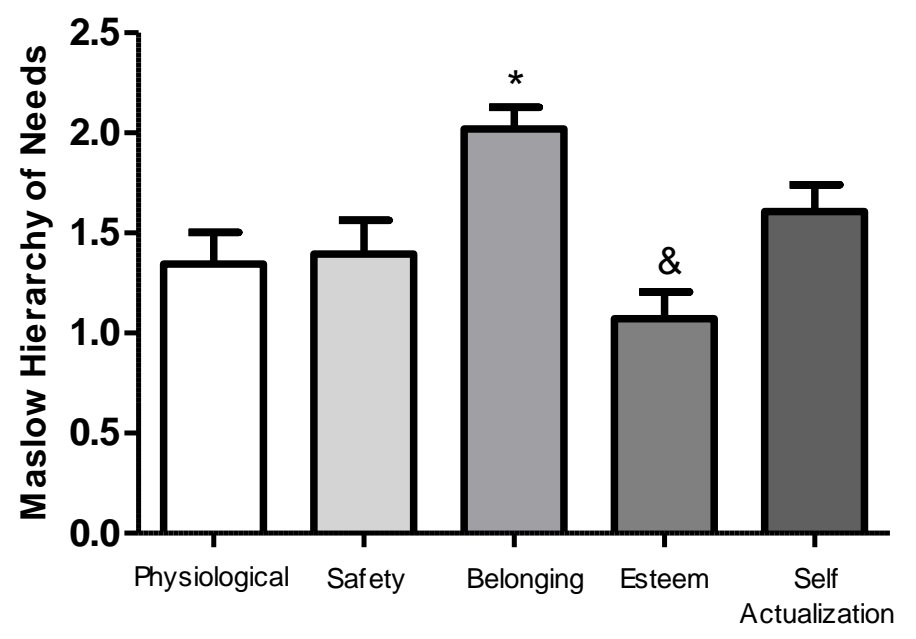

Source: The authors, (2021).

Analyzing the motivation results, in Figure 3 belonging is the biggest source of job motivation among nurses in BHUs and esteem is the lowest need. Statistical analysis was conducted by the Kruskal-Wallis test followed by Dunn's multiple comparison tests. $*$, \& P-value $<0.001$. * Belonging is significantly different than other needs. And Esteem is significantly different than other needs.

Examining the nurse' needs, the aspiration "To increase my income", is the Physiological need that motivates most (M: 2.20, SD: 1.15); at Safety needs, all results are lower than 2 except "To make my job more secure" (M: 2.63, SD: 0.71). "To make more friends in my working environment" received the higher score at Belonging (M: 2.66, SD: 0.80). The desire "to be respected" was the highest ranked motivator in Esteem (M: 2.56, SD: 0.89), and finally, the desire "To develop my potential" was the Self-actualization need with bigger media scores (M: 2.53, SD: 1.1).

Moreover, the correlation test was performed on Table 2 showed that Physiological needs are positively correlated with Safety needs. Besides that, a significant negative correlation was found between Physiological and Self-actualization. 
Table 2. Correlation values between Maslow's Hierarchical Needs.

\begin{tabular}{lllll}
\hline & & Correlation & P & Sig \\
\hline $\begin{array}{l}\text { Physiological } \\
\text { Safety }\end{array}$ & $\&$ & 0,318 & 0,027 & $*$ \\
$\begin{array}{l}\text { Physiological } \\
\text { Belonging }\end{array}$ & $\&$ & $-0,055$ & 0,709 & Ns \\
$\begin{array}{l}\text { Physiological } \\
\text { Esteem }\end{array}$ & $\&$ & $-0,156$ & 0,289 & Ns \\
$\begin{array}{l}\text { Physiological } \\
\text { Self-Actualization }\end{array}$ & \& & $-0,396$ & 0,005 & $* *$ \\
$\begin{array}{l}\text { Safety } \\
\text { Belonging }\end{array}$ & 0,003 & 0,981 & Ns \\
$\begin{array}{l}\text { Safety \& Esteem } \\
\text { Safety\&Self- } \\
\text { Actualization }\end{array}$ & $\&$ & 0,043 & 0,769 & Ns \\
$\begin{array}{l}\text { Belonging } \\
\text { Esteem }\end{array}$ & $-0,009$ & 0,947 & Ns \\
$\begin{array}{l}\text { Belonging \& } \\
\text { Actualization }\end{array}$ & Self- & $-0,198$ & 0,176 & Ns \\
$\begin{array}{l}\text { Esteem \& Self- } \\
\text { Actualization }\end{array}$ & $-0,125$ & 0,34 & Ns \\
\hline
\end{tabular}

Source: The authors, (2021).

In Table 2 is possible observed the significance between Physiological \& Safety and Physiological \& SelfActualization.

\section{Discussion}

The concept of management and assistant are still seen separately, but management is one of the pillars of support for quality care, and it's common that nurses are responsible for both functions (Sarafis et al., 2016). But a potential problem related to the development of two different activities is the appearance of occupational stress. Stress is heavily influenced by the work environment and will affect the nurse's performance with a negative impact on nurse's health (Arnetz, Sudan, Goetz, Counts, \& Arnetz, 2019; Copanitsanou, Fotos, \& Brokalaki, 2017).

The National Healthcare System in Brazil presents many positive points as an effective social control with a reduction of hospitalizations, declining infant and maternal mortality, increasing the vaccination coverage, and preventing a hypertension and diabetes crisis in population. But some deficiencies mostly made by the poor infrastructure and it could impact in nurse's behavior in these workplaces. When the total stress score at the group is investigated, it reveals that nurses are suffering from moderate stress score. Analyzing the data separately, the results showed that $44.7 \%$ of nurses presented high-stress scores and a minor group low stress levels. The research of stress in teamwork usually ignores a single person and has the main focus based on the total group results, but typically at BHUs, there is just one nurse that concentrated the assistance and management work, and in this case, the individual member should be prioritized.

In accordance with the Department of Health in 2011, 30\% of nurses report experiencing work-related stress, as the consequence, more than half of this number wants to quit their jobs as soon as they can find another one (Farquharson et al., 2013). Our results emphasize that at BHUs, $89.4 \%$ of nurses present from moderate to higher stress scores that could directly affect the daily lives of nurses and interfere with the quality of the health care users.

In this investigation, the female predomination was again demonstrated. Countries as Canada and the United States, women represent $95 \%$ of nurses (Zamanzadeh et al., 2013). 
Considering that primary health care is the first level of contact that community has with the health care system, and nurses are the backbone of this organization, nurses' emotional exhaustion could resound at the client with significant effects on patients' health Considering that primary health care is the first level of contact that the community has with the health system, and nurses are the backbone of this organization, nurses 'emotional exhaustion can resonate in the client with significant effects on patients' health. In other words, physiological mechanisms associated with the work environment can negatively impact patient safety, in addition to the nurse's health (Arnetz, Sudan, Goetz, Counts, \& Arnetz, 2019). Besides that, the stressful nature of nursing often leads to burnout, low productivity, and absenteeism (Pulido-Martos et al., 2012). But the consequence of stress is not only upon work performance, but occupational stress may also significantly affect nurse's quality of life and it is extremely associated with mental health problems (Copanitsanou et al., 2017).

Developing countries adopted decentralization as a measure of structural and financial reform, but as a consequence, implications in human resources were observed during this process (Kolehmainen-Aitken, 2004). Investigating the main sources of stress in BHUs, the vast majority of respondents complained about the intrinsic work factors. It includes long hours shift, work overload, inadequate supply, staff reduction, and poor physical work conditions. Investigating the main sources of stress in the UBS, the vast majority of respondents complained about factors intrinsic to work. It includes long hours shifts, work overload, inadequate supply, reduced staff and poor physical working conditions. It is already known that intense workloads associated with frequency and rhythm with varied demands can interfere with the quality of life at work (Martinez \& Fischer, 2019).

Conversely, the low cause of stress in BHUs was the Interpersonal relationship, this is an important observation once the low social support of co-workers can generate occupational stress (Theörell, 2020). At BHUs, the Interpersonal relationship is not only between nurses and client but the interaction with all health professionals inside the Health Units. The literature provides concerns about these interactions (Martins et al., 2014), especially the nurse-physician relationships, but our results demonstrated a good interaction with the work team and low leaves of stress were found in this factor.

Occupational phenomena are intimately linked to job satisfaction and motivation (Somense \& Duran, 2014). Motivation is as an abstract idea, and to assess nurse' motivation was to apply the Maslow Theory based on the hierarchy of importance. Maslow affirms that humans have five levels of needs, and once one need is satisfied, another emerges to replace it (Benson \& Dundis, 2003; Maslow, 1943). In this way, it was expected the dominance of basic needs, with less concern for higher needs, or the opposite, a greater concern with higher needs.

The results showed low interest in Physiological and Safety needs, one possibility is the fulfiller of these needs, once physiological needs are a biological and physical requirement, and safety needs are related with economic, social, vocational, psychological necessity. At BHUs, the Safety needs are probably satisfied with the security offered by the employment. Moreover, the correlation analysis showed a positive correlation between Physiological and Safety Needs, once both are placed at the bottom of the pyramid and extremely associated.

The sense of belonging is a fundamental human need (Grobecker, 2016). BHUs are located in the middle of communities creating strong social connections with the population and impacting positively on nurse's motivation, and in accordance with the report from Ministry of Health, all families know the members of the BHUs, it's demonstrated by the higher score between nurses in BHUs using the Maslow hierarchy of Needs.

Esteem is the fourth layer of Maslow's model of human motivation and it is considerate a status needs (Sarafis et al., 2016). Nurses with a positive self-esteem transmit confidence and respect to the clients, and in turn, expects appreciation and respect (Toode et al., 2011). But it's important to emphasize that esteem is just reached once belonging and the basic needs are completely achieved (Juth et al., 2008). During the analysis of the results, esteem presented the lowest value in this hierarchical investigation, showing that belonging, even with the good values in this analysis, wasn't fully attained. 
The well-known Maslow's pyramid of human needs places the need to self-actualization at the highest level—the apex as a supreme need. According to this model, the motivation to meet advanced needs depends on fulfilment of more basic needs of the lower levels (Hazanov et al., 2020). Self-actualization is related to integrity, imagination, improvisation, and rationality, but as the last need, is the harder to achieve. Besides that, a significant negative correlation was found between Physiological and Self-Actualization.

\section{Final Considerations}

In healthcare organizations, a motivated work team contributes to the healthcare results and delivery performance. But understanding the fragilities of the working environment is crucial for the development of strategies that could improve the result inside BHUs, once the debilities could affect the healthcare delivery processes with a negative impact on a work team of nurses. In this way, this research reveals the strong impact caused by the intrinsic work factors upon the nurse's stress, and to reduces the occupational risk, as a preventive measure, it's important to reduce the lack of human resources, one of the most critical issues inside the BHUs.

\section{Acknowledgments}

Preparation of this paper was made possible with support from the Basic Health Units involved in this investigation.

\section{References}

Arnetz, J., Sudan, S., Goetz, C., Counts, S., \& Arnetz, B. (2019). Nurse work environment and stress biomarkers: Possible implications for patient outcomes. Journal of Occupational and Environmental Medicine, 61(8), 676-681.

Benson, S. G., \& Dundis, S. P. (2003). Understanding and motivating health care employees: Integrating Maslow's hierarchy of needs, training and technology. Journal of Nursing Management, 11(5), 315-320. https://doi.org/10.1046/j.1365-2834.2003.00409.x

Braithwaite, M. (2008). Nurse burnout and stress in the NICU. Advances in Neonatal Care: Official Journal of the National Association of Neonatal Nurses, 8(6), 343-347. https://doi.org/10.1097/01.ANC.0000342767.17606.d1

Carvalho, B. G., Peduzzi, M., Nunes, E. de F. P. de A., Leite, F. de S., \& Silva, J. A. M. da. (2014). Management of basic health units in municipalities of different size: profile and management instruments. Revista Da Escola de Enfermagem Da USP, 48(5), 907-914. https://doi.org/10.1590/S00806234201400005000018

Copanitsanou, P., Fotos, N., \& Brokalaki, H. (2017). Effects of work environment on patient and nurse outcomes. British Journal of Nursing, 26(3), 172-176. https://doi.org/10.12968/bjon.2017.26.3.172

Cumber, N. S., \& Elive, S. M. (2016). The Identification of Motivational Factors That Influences Nurses Output in Hospitals in the Fako Division, Cameroon. Journal of Family Medicine and Health Care, 2(4), 74. https://doi.org/10.11648/j.jfmhc.20160204.18

Farquharson, B., Bell, C., Johnston, D., Jones, M., Schofield, P., Allan, J., Ricketts, I., Morrison, K., \& Johnston, M. (2013). Nursing stress and patient care: Real-time investigation of the effect of nursing tasks and demands on psychological stress, physiological stress, and job performance: Study protocol. Journal of Advanced Nursing, 69(10), 2327-2335. https://doi.org/10.1111/jan.12090

Gragnolati, M., Lindelow, M., \& Couttolenc, B. (2013). 20 anos de construção do Sistema de Saúde no Brasil - Uma análise do Sistema Único de Saúde. In The Workd Bank. https://doi.org/10.1596/978-0-8213-9843-2

Grobecker, P. A. (2016). A sense of belonging and perceived stress among baccalaureate nursing students in clinical placements. Nurse Education Today, 36, 178-183. https://doi.org/10.1016/j.nedt.2015.09.015

Hazanov, Y., Gehman, Y., Wilf Miron, R., \& Kagan, I. (2020). Nursing work environment, professional self-actualization and marketing of the nursing profession: Cross-sectional study. Nursing Open, 8(1), 434-441. https://doi.org/10.1002/nop2.644

Jennings, B. M. (2008). Work Stress and Burnout Among Nurses: Role of the Work Environment and Working Conditions. In Patient Safety and Quality: An Evidence-Based Handbook for Nurses. Agency for Healthcare Research and Quality (US). http://www.ncbi.nlm.nih.gov/pubmed/21328768

Juth, V., Smyth, J. M., \& Santuzzi, A. M. (2008). How do you feel? Self-esteem predicts affect, stress, social interaction, and symptom severity during daily life in patients with chronic illness. Journal of Health Psychology, 13(7), 884-894. https://doi.org/10.1177/1359105308095062

Kahiga, K. W. (2017). Factors influencing the job satisfaction of nurses working in obstetric units in public hospitals in Kenya. Journal of Nursing Education and Practice, $8(2), 132$. https://doi.org/10.5430/jnep.v8n2p132 
Kolehmainen-Aitken, R. L. (2004). Decentralization's impact on the health workforce: Perspectives of managers, workers and national leaders. In Human Resources for Health (Vol. 2, Issue 1, pp. 1-11). BioMed Central. https://doi.org/10.1186/1478-4491-2-5

Leonelli, L. B., Andreoni, S., Martins Ii, P., Harumi, E., Iii, K., Lúcia De Salvo, V., Sopezki, D., Montero-Marin, J., Iv, J., Garcia-Campayo, V., Marcos, M., Demarzo, P., Piva, M. M., \& Botucatu, D. R. (2017). Estresse percebido em profissionais da Estratégia Saúde da Família. Revista Brasileira de Epidemiologia, 20(202), 286-298. https://doi.org/10.1590/1980-5497201700020009

Martins, C. C. F., Santos, V. E. P., Pereira, M. S., \& dos Santos, N. P. (2014). the Nursing Team'S Interpersonal Relationships V. Stress: Limitations for $\begin{array}{llll}\text { Practice. } & \text { Cogitare } & \text { Enfermagem, } & \text { 287-293 }, ~\end{array}$ http://ahs.idm.oclc.org/login?url=http://search.ebscohost.com/login.aspx?direct=true\&db=rzh\&AN=103974299\&site=ehost-live

Maslow, A. H. (1943). A Theory of Human Motivation. Psychological Review, 50(4), 370-396. https://doi.org/10.1037/h0054346

McKnight, J., Nzinga, J., Jepkosgei, J., \& English, M. (2020). Collective strategies to cope with work related stress among nurses in resource constrained settings: An ethnography of neonatal nursing in Kenya. Social Science and Medicine, 245. https://doi.org/10.1016/j.socscimed.2019.112698

Oliveira, A. P. C. de, Gabriel, M., Poz, M. R. D., \& Dussault, G. (2017). Challenges for ensuring availability and accessibility to health care services under Brazil's Unified Health System (SUS). Ciência \& Saúde Coletiva, 22(4), 1165-1180. https://doi.org/10.1590/1413-81232017224.31382016

Pulido-Martos, M., Augusto-Landa, J. M., \& Lopez-Zafra, E. (2012). Sources of stress in nursing students: A systematic review of quantitative studies. In International Nursing Review, 59(1), 15-25. https://doi.org/10.1111/j.1466-7657.2011.00939.x

Regis, V. L. F. L., \& Porto, I. S. (2011). Basic human needs of nursing professional: Situations of (dis)satisfaction at work. Revista da Escola de Enfermagem, 45(2), 332-338. https://doi.org/10.1590/S0080-62342011000200005

Sarafis, P., Rousaki, E., Tsounis, A., Malliarou, M., Lahana, L., Bamidis, P., Niakas, D., \& Papastavrou, E. (2016). The impact of occupational stress on nurses' caring behaviors and their health related quality of life. BMC Nursing, 15(1), 1-9. https://doi.org/10.1186/s12912-016-0178-y

Sauter, S., Murphy, L., Colligan, M., Swanson, N., Hurrell, J. J., Scharf, F. J., Grubb, R. S. P., Goldenhar, L., Alterman, T., Johnston, J., Hamilton, A., \& Tisdale, J. (1999). Stress At Work. National Institute for Occupational Safety and Health, 99(101), 1-32. https://doi.org/http://www.cdc.gov/niosh

Somense, C. B., \& Duran, E. C. (2014). Satisfaction/Motivation of Nurses: Integrative Review. J Nurs UFPE onLine, 8(87), 3172-813172. https://doi.org/10.5205/reuol.5960-55386-1-ED.0809201428

Stacciarini, J. M. R., \& Tróccoli, B. T. (2000). Instrumento para mensurar o estresse ocupacional: Inventário de Estresse em Enfermeiros (IEE). Revista Latino-Americana de Enfermagem, 8(6), 40-49. https://doi.org/10.1590/S0104-11692000000600007

Toode, K., Routasalo, P., \& Suominen, T. (2011). Work motivation of nurses: A literature review. International Journal of Nursing Studies, 48(2), 246-257. https://doi.org/10.1016/j.ijnurstu.2010.09.013

Viana, A. L. D., \& Machado, C. V. (2008). Proteção social em saúde: um balanço dos 20 anos do SUS. Physis: Revista de Saúde Coletiva, 18(4), 645-684. https://doi.org/10.1590/S0103-73312008000400004

Wang, X., \& Cheng, Z. (2020). Cross-Sectional Studies: Strengths, Weaknesses, and Recommendations. Chest, 158(1), S65-S71. https://doi.org/10.1016/j.chest.2020.03.012

WHO. (2010). Workload Indicators of Staffing Need: USER'S MANUAL. World Health Organization.

Zamanzadeh, V., Valizadeh, L., Negarandeh, R., Monadi, M., \& Azadi, A. (2013). Factors influencing men entering the nursing profession, and understanding the challenges faced by them: Iranian and developed countries perspectives. Nursing and Midwifery Studies, 2(4), 49-56. http://www.ncbi.nlm.nih.gov/pubmed/25414879 